\title{
Tularemija - prikaz dveh primerov pri otrocih
}

\section{Tularaemia - Two Case Reports in Children}

Karmen Tašner, Aneta Nikolova, Aleksandra Zorko - Brodnik, Vojko Berce

\section{Izvleček}

Tularemija je zoonoza, ki se pri otrocih pojavlja redko, a jo moramo vključiti $v$ diferencialno diagnozo vnetja bezgavk in nepojasnjene vročine, predvsem ko so v epidemiološki anamnezi prisotni dejavniki tveganja.

$\checkmark$ prispevku predstavljamo značilnosti bolezni in prikažemo primera dveh otrok s tularemijo. Posebno pozornost namenjamo klinični sliki in različnim oblikam bolezni.

Navajamo tudi diferencialnodiagnostične možnosti, osnovne preiskave in terapevtsko ukrepanje.

Ključne besede: tularemija, zoonoza, limfadenopatija, vročina, prikaz primerov. 


\section{Uvod}

\section{Epidemiologija}

Tularemija je redka infekcijska bolezen, ki jo povzroča po Gramu negativna bakterija Francisella tularensis; je zoonoza $(1,2)$. Po podatkih Nacionalnega inštituta za javno zdravje (NIJZ) znaša v Sloveniji desetletno povprečje števila prijav 1,3 prijave/leto (3). Glavni rezervoar tularemije $v$ Sloveniji so predvsem zajci, veverice, pižmovke, bobri in divjad. Bolezen se na človeka prenaša ob stiku z okuženo živaljo, redkeje tudi ob ugrizu klopa, ki se je predhodno hranil na okuženi živali. Okužba je možna tudi z zaužitjem kontaminirane hrane, vode ali z vdihovanjem aerosola in prahu (4). S človeka na človeka se ne prenaša (5). Inkubacijska doba je 1-21 dni (3).

\section{Klinična slika in oblike bolezni}

Klinična slika sega od blage oblike bolezni do življenje ogrožajoče oblike (6). Obstaja več podtipov tularemije.

Ulceroglandularna in glandularna oblika (80 \% vseh primerov) sta najpogostejši obliki bolezni, diagnosticirani pri otrocih. Po 48-72 urah se na mestu stika z okuženo živaljo ali na mestu vboda klopa pojavi papula, ki je trda, eritematozna, lahko tudi srbeča. Papula nekrotizira in nastane boleča razjeda $z$ dvignjenim robom in s temno bazo, ki vztraja 1-3 tedne. Hkrati se pojavi področna limfadenopatija; področne bezgavke se lahko povečajo do $10 \mathrm{~cm}$, povečana je lahko ena bezgavka ali skupina bezgavk. Povečana bezgavka lahko s časom fluktuira in fistulira, lahko pa se tvorijo tudi granulomi. Pri glandularni obliki gre za prizadetost bezgavk brez začetne spremembe na koži $(1,2)$.

Pljučna tularemija se kaže kot intersticijska pljučnica in je posledica inhalacije bakterij v aerosolu. Gre za redko obliko tularemije $(1,5)$.

Orofaringealna tularemija se pojavi po zaužitju kontaminirane vode ali slabo toplotno obdelanega mesa. V klinični sliki opažamo akutni eksudativni tonzilofaringitis, prisotna je izrazita limfadenopatija na vratu $(1,6)$.

Pri okuloglandularni obliki je vstopno mesto veznica, prenos okužbe pa poteka prek kontaminiranih prstov. Kaže se kot boleč gnojni konjunktivitis z noduli in točkovnimi razjedami. Prisotna je ipsilateralna predušesna ali podčeljustna limfadenopatija $(1,6)$.

Tifoidna oblika se kaže $z$ vročino neznanega izvora in znaki endotoksemije ter brez pomembne prizadetosti bezgavk. Otroci so praviloma kritično bolni in septičnega videza. Prizadeta so prebavila, prisotne so bolečine $v$ žrelu in trebuhu, razvije se lahko fulminantna in usodna bolezen $(1,7)$.

\section{Diagnosticiranje}

Za diagnosticiranje sta pomembna dobra (predvsem epidemiološka) anamneza in natančen klinični status. Izvidi laboratorijskih preiskav so neznačilni, število levkocitov je lahko povečano ali normalno, hitrost sedimentacije eritrocitov in C-reaktivni protein (CRP) sta v večini zmerno povečana $(1,7)$. Tularemijo večinoma diagnosticiramo s serološkim testom z metodo indirektne imunofluorescence ali testa aglutinacije, ki je pozitiven pri vrednosti titra IgG in/ali IgM $\geq 1: 160$ pri bolniku s pozitivno anamnezo in ustrezno klinično sliko $(8,9)$. Štirikratno povišanje titra protiteles v razmiku 2-3 tedne je prav tako diagnostično. Zgodaj v poteku bolezni je lahko serološko testiranje lažno negativno (protitelesa se namreč začnejo pojavljati $14 \mathrm{dni}$ po začetku bolezenskih znakov), $30 \%$ bolnikov pa ima serološke teste pozitivne šele po treh tednih. Po okužbi imajo lahko bolniki doživljenjsko pozitiven aglutinacijski test (7). Hemokultura je pozitivna v približno $10 \%$. V bioptu bezgavke je viden vzorec z geografskimi predeli nekroze z nevtrofilci, ki pa ni specifičen, saj je prisoten tudi pri drugih okužbah bezgavk. Povzročitelja lahko osamimo tudi iz brisa raz- jede, drenirane bezgavke ali izmečka $(1,8)$. Za kultivacijo $F$. tularensis je potreben čokoladni agar, zato moramo ob sumu na tularemijo to posebej označiti, tudi zaradi kužnosti vsakega vzorca (8). V zadnjem času za dokaz genoma povzročitelja iz brisa ali biopta uporabljamo predvsem verižno reakcijo s polimerazo (angl. polymerase chain reaction, $\mathrm{PCR})(1,8)$.

\section{Diferencialna diagnoza}

Med diferencialnodiagnostičnimi možnostmi pridejo v poštev bolezen mačje praske (Bartonella henselae), infekcijska mononukleoza, Kawasakijev sindrom, bakterijska okužba bezgavk, okužba s Toxoplasmo gondii, tuberkuloza in okužba bezgavk z netuberkuloznimi mikrobakterijami, antraks, leptospiroza, herpes simpleks, adenoviroza, bruceloza, limfom in sepsa $(1,7)$.

\section{Zdravljenje}

Zdravljenje izbire je gentamicin v odmerku 5 mg/kg/24 ur intravensko oz. intramuskularno ali streptomicin 30-40 mg/kg/24 ur im., zdravljenje pa naj traja 7-10 dni. Pozen pojav utekočinjenja in fistuliranja bezgavke se lahko pojavi kljub ustreznem zdravljenju. Utekočinjene bezgavke moramo kirurško drenirati $(1,6)$.

\section{Klinična primera}

Za objavo obeh predstavljenih kliničnih primerov smo pridobili soglasje staršev.

\section{Primer 1}

Šestletni deček je bil hospitaliziran zaradi dva tedna trajajočega vročinskega stanja do $39{ }^{\circ} \mathrm{C}$ in povečanih bezgavk na vratu obojestransko do velikosti $3 \mathrm{~cm}$, ki so bile premakljive, elastične in blago boleče na palpacijo, v ostalem pa je bil klinični status ob sprejemu v mejah normalnih vrednos- 
ti. Zadnjih šest mesecev je imel tudi bolečine $v$ trebuhu. Pred sprejemom je zaradi suma na bakterijski tonzilitis že prejel antibiotično zdravljenje s penicilinom in nato še s kombinacijo amoksicilina in klavulanske kisline, a ob tem ni prišlo do izboljšanja.

V laboratorijskih izvidih so bile ob sprejemu prisotne normocitna anemija (hemoglobin $102 \mathrm{~g} / \mathrm{l}$ ) pospešena hitrost sedimentacije eritrocitov (71 mm/h) in blago zvišane vrednosti CRP (18 mg/l), vrednost levkocitov je bila $11,3 \times 10^{9} /$.

Opravljene mikrobiološke preiskave (tuberkulinski test, mikrobiološke preiskave blata, serologija na $B$. henselae, B. quintana, T. gondii, virus EpsteinBarr in citomegalovirus ter PCR multiplex bris nazofarinksa na viruse in atipične bakterije) so bile negativne ali so kazale na staro okužbo. Ultrazvočna preiskava trebuha in rentgenski (RTG) posnetek pljuč nista pokazala posebnosti. Ultrazvok vratu je pokazal številne povečane bezgavke obojestransko na vratu do velikosti $30 \mathrm{~mm}$.

Zaradi podatka o nekaj mesecev trajajočih bolečinah $v$ trebuhu so bile opravljene še druge diferencialnodiagnostične preiskave, ki so bile prav tako vseskozi v mejah normalnih vrednosti. Med hospitalizacijo je deček postal afebrilen, bezgavke so se zmanjšale, tek se je izboljšal, tudi laboratorijski izvidi so kazali tendenco normalizacije, zato je bil deček odpuščen. Antibiotično zdravljenje $z$ amoksicilinom in s klavulansko kislino je bilo zaključeno med hospitalizacijo in jo je skupno prejemal $10 \mathrm{dni}$, nadaljnjega zdravljenja doma nismo svetovali.

Ob odpustu so bile tipne bezgavke velikosti do $2 \mathrm{~cm}$ obojestransko na vratu, mehke, premakljive, elastične in neboleče, zato diagnostične punkcije nismo izvedli.

Po dveh tednih od hospitalizacije je deček opravil kontrolni pregled $v$ naši hematološki ambulanti, kjer so ugotavljali ponovno povečanje bez- gavk, tokrat samo levostransko. Ob tem ni več imel povišane temperature, bil je nekoliko nahoden, ob tem ves čas utrujen, ponovno je tožil zaradi bolečin v trebuhu. Starši so povedali, da se deček že dlje ponoči veliko poti. Ponovno smo ga hospitalizirali, opravili UZ preiskavo vratu, ki je pokazala številne ovalne bezgavke obojestransko na vratu, velikosti do $15 \mathrm{~mm}$ x $30 \mathrm{~mm}$ brez utekočinjenja. Opravili smo citološko punkcijo, ki je kazala na nespecifično akutno vnetje. V laboratorijskih izvidih je bila hitrost sedimentacije eritrocitov $70 \mathrm{~mm} / \mathrm{h}$, ostali izvidi so bili v mejah normalnih vrednosti.

Ob ponovni podrobnejši anamnezi smo od mame naknadno izvedeli, da je bil deček v stiku z zajci, ki jih imajo doma, zato smo še enkrat odvzeli kri za serologijo na $B$. henselae in prvič na F. tularensis. Izvidi seroloških preiskav na tularemijo so bili močno pozitivni ( $\lg G>1: 512, \lg M>1: 512)$. Dodatno smo iz dela tkiva, ki je bil že predhodno odvzet $z$ aspiracijsko biopsijo bezgavke, opravili še PCR na F. tularensis, izvid je bil prav tako pozitiven. Pri dečku je bila tako ugotovljena glandularna oblika tularemije, zato je prejel intravensko zdravljenje z gentamicinom skupaj $10 \mathrm{dni}$.

Po zdravljenju so se bezgavke na vratu zmanjšale na normalno velikost.

\section{Primer 2}

Petletna deklica je bila obravnavana najprej v infektološki ambulanti. Utrpela je ugriz treh klopov - v predelu popka, desno ledveno in levo v višini rebrnega loka pod pazduho, pri čemer so klope odstranili v roku 24 ur. Po šestih dneh od vboda je deklica začela tožiti zaradi bolečin $v$ predelu pod levo pazduho, kjer so zatipali za lešnik veliko bolečo zatrdlino, koža nad njo ni bila pordela, poškodbo so zanikali. Pojavila se je vročina do $39,5{ }^{\circ} \mathrm{C}$. Zatrdlina pod levo prsno mišico je bila ob pregledu v infektološki ambulanti velika približno $2 \mathrm{~cm} \times 1 \mathrm{~cm}$, palpatorno boleča, koža nad njo nespreme- njena, kavdalno, tj. na mestu vboda klopa, je bila vidna manjša razjeda, pokrita s krusto, okrog razjede pa se je širila rdečina. V laboratorijskih izvidih je bila vrednost hemoglobina 118 $\mathrm{g} / \mathrm{l}$, levkocitov 6,28 x 10\%/, CRP $59 \mathrm{mg} / \mathrm{l}$. Opravljen je bil ultrazvok spremembe, kjer je bilo ugotovljeno, da je vidna izboklina zagnojena bezgavka velikosti $17 \mathrm{~mm}$ x 10 mm, nekoliko bolj kranialno je bil viden paket vnetno spremenjenih bezgavk, tik ob paketu pa še ena utekočinjena bezgavka velikosti 17 x $12 \mathrm{~mm}$. Uvedeno je bilo antibiotično zdravljenje s kombinacijo amoksicilina in klavulanske kisline, za drenažni izrez abscesa pa se kirurg zaradi majhnosti abscesa ni odločil.

Po jemanju antibiotika ni prišlo do izboljšanja. Odvzeta je bila serologija na $B$. henselae in na $F$. tularensis. Izvid serologije na tularemijo je bil močno pozitiven (IgM in IgG > 1:512), ob tem je klinična slika ustrezala ulceroglandularni obliki tularemije, zato je deklica prejela intravensko antibiotično zdravljenje z gentamicinom, ki ga je prejemala skupaj $10 \mathrm{dni}$.

Po zaključenem zdravljenju se je pri deklici nekrotična bezgavka levo na prsnem košu izpraznila s fistulacijo, koža nad bezgavko se je nato zarasla. Ostale povečane bezgavke so povsem regredirale in po nekaj tednih niso bile več tipno povečane.

\section{Razprava}

V prispevku predstavljamo tularemijo - redko infekcijsko bolezen v otroškem obdobju, in opišemo dva primera okužbe otroka s tularemijo, ki sta bila obravnavana na Kliniki za pediatrijo, UKC Maribor v letu 2016 oz. 2017. V prvem primeru je šlo za glandularno obliko tularemije, katere najverjetnejši vektor je bil zajec, v drugem primeru pa za ulceroglandularno obliko, katere vektor je bil klop.

$\checkmark$ prvem primeru je šlo za relativno blag, nespecifičen in protrahiran potek 
bolezni, pri katerem je bila za postavitev diagnoze ključna dopolnjena in natančna epidemiološka anamneza o stiku z zajcem. Zelo verjetno je, da veliko podobnih primerov ostane neodkritih, na kar kaže razkorak med zelo nizkim številom prijavljenih primerov tularemije in znatno višjim deležem seropozitivnih (približno $2 \%$ ) v raziskavi, ki je bila izvedena na Finskem (6).

Še posebej izstopa drugi primer, kjer je bila okužba prenesena s pikom klopa, kar je po podatkih Inštituta za mikrobiologijo (Ljubljana) prvi tovrstni prenos tularemije, zaznan na območju Vzhodne Slovenije. Prenos F. tularensis preko klopa v splošnem zelo redko opažamo tudi na širšem območju Evrope, posebej redko pri otrocih (2).

Za postavitev diagnoze je bila v obeh primerih ključna dobra epidemiološka anamneza, saj zaradi njene redkosti in klinične prezentacije, ki spominja na številna druga pogostejša stanja, na tularemijo praviloma pomislimo šele pozno v poteku bolezni.

Po podatkih Evropskega centra za preprečevanje in obvladovanje bolezni (angl. European Centre for Disease Prevention and Control) je najvišja stopnja pojavnosti tularemije v Evropi v Skandinavskih državah, ki so endemsko območje in kjer opažajo tudi veliko število okužb preko ugrizov komarjev, kar drugod po Evropi ni značilno (10). Po podatkih iz leta 2018 so bili v Sloveniji prijavljeni štirje primeri tularemije, v letu 2017 en primer, v letu 2016 pa trije primeri, podobno nizko število primerov opažamo tudi v sosednjih državah (10), nekoliko višje je v posameznih letih število prijavljenih na Madžarskem, kar pripisujejo večjemu številu voluharjev na tem območju (11).

\section{Zaključek}

Tularemija je $v$ našem okolju zelo redka zoonoza. Okužbe se v Evropi najpogosteje prenašajo preko glodavcev, $v$ redkih primerih pa tudi preko klopov.
Zaradi pestre klinične slike, ki spominja na številne druge in pogostejše bolezni, je za postavitev diagnoze ključna natančna epidemiološka anamneza. To velja tudi za opisana primera. Verjetno pa znaten delež primerov tularemije poteka blago in samoomejujoče ter zato ostane nespoznan, kar velja predvsem za okolja, kjer se bolezen redko pojavlja.

\section{Literatura}

1. Rajter M. Tularemija. In: Tomažič J, Strle F, eds. Infekcijske bolezni. 1st ed. Ljubljana: Združenje za infektologijo, Slovensko zdravniško društvo, 2014: 517-8.

2. Hestvik G, Warns-Petit E, Smith LA, Fox NJ, Uhlhorn $\mathrm{H}$, Artois $\mathrm{M}$, et al. The status of tularemia in Europe in a one-health context: a review. Epidemiol Infect 2015; 143: 2137-60.

3. Dosegljivo na: http://www.nijz.si/sl/tularemija/. 4. Lang S, Kleines M. Two at one blow: reemergence of tularemia in Upper Austria. New Microbiol 2012; 35: 349-52.

5. Kugeler KJ, Mead PS, McGowan KL, Burnham $J M$, Hogarty MD, Ruchelli E, et al. Isolation and characterization of a novel Francisella sp. from human cerebrospinal fluid and blood. J Clin Microbiol 2008; 46: 2428-31.

6. Rossow $\mathrm{H}$, Ollgren J, Hytonen J, Rissanen $\mathrm{H}$, Huitu O, Henttonen, et al. Incidence and seroprevalence of tularaemia in Finland, 1995 to 2013: regional epidemics with cyclic pattern. Euro Surveill 2015; 20: 21209

7. Johansson A, Petersen J, Sjöstedt A. Laboratory diagnostics and discrimination of subspecies and strains, In: Tärnvik A, ed, WHO guidelines on tularemia. Geneva: World Health Organization, 2007: 27-34.

8. Ellis J, Oyston PC, Green M, Titball RW. Tularemia. Clin Microbiol Rev 2002; 15: 631-46.

9. Grunow R, Splettstoesser W, McDonald S, Otterbein C, O'Brien T, Morgan C, et al. Detection of Francisella tularensis in biological specimens using a capture enzyme-linked immunosorbent assay, an immunochromatographic handheld assay, and a PCR. Clin Diagn Lab Immunol 2000; 7: 86-90.

10. Dosegljivo na: http://www.ecdc.europa.eu/ sites/default/files/documents/tularaemia-annual -epidemiological-report-2018.pdf/.

11. Maurin M, Gyuranecz M. Tularaemia: clinical aspects in Europe. Lancet Infect Dis 2016; 16: $113-24$.
Karmen Tašner, dr. med.

Zdravstveni dom Ptuj, Ptuj, Slovenija

Aneta Nikolova, dr. med.

Zdravstveni dom Kranj, Kranj, Slovenija

Aleksandra Zorko - Brodnik, dr. med.

Klinika za pediatrijo,

Univerzitetni klinični center Maribor,

Maribor, Slovenija

doc. dr. Vojko Berce, dr. med.

(kontaktna oseba / contact person)

Klinika za pediatrijo,

Univerzitetni klinični center Maribor,

Ljubljanska ulica 5,

2000 Maribor, Slovenija

e-naslov: vojko.berce@guest.arnes.si

prispelo / received: 24. 5. 2020

sprejeto / accepted: 14. 8. 2020

Tašner K, Nikolova A, Zorko Brodnik A, Berce $V$. Tularemija - prikaz dveh primerov pri otrocih. Slov Pediatr 2020; 27(4): 183-187. https://doi. org/10.38031/ slovpediatr-2020-4-05. 